\title{
Molecular simulations of peptides and proteins with Molecular Fragment Dynamics (MFD)
}

\author{
Andreas Truszkowski ${ }^{1 *}$, Annamaria Fiethen ${ }^{2}$, Hubert Kuhn ${ }^{2}$, Achim Zielesny $^{3}$, Matthias Epple $^{1}$ \\ From 8th German Conference on Chemoinformatics: 26 CIC-Workshop \\ Goslar, Germany. 11-13 November 2012
}

Molecular Fragment Dynamics (MFD) is a mesoscopic simulation technique based on dissipative particle dynamics. The method has been shown to successfully describe the phase behaviour and interfacial tensions of large chemical systems in good agreement with experimental results [1]. Unlike molecular mechanics a MFD simulation is based on "coarse-grained" molecular fragments rather than "fine-grained" atom types.

The current MFD fragment definition is based on a SMILES like one-dimensional line notation which is visualized with the Structure Diagram Generator of the Chemistry Development Kit (CDK) [2]. For an extension of the MFD technique to chemical ensembles containing peptides and proteins an appropriate molecular fragment cheminformatics tool for their design is in need.

This work provides an editor for the construction of peptides and proteins from molecular fragments. It includes building blocks for all 20 proteinogenic amino acids, their charged species and disulfide bonds. A flexible input of one-letter and three-letter amino acid codes is supported. Additionally, the editor has the capability to set charges of side chains manually or automatically.

\section{Author details}

'Inorganic Chemistry and Center for Nanointegration, University of DuisburgEssen, Essen, 45141, Germany. ${ }^{2}$ CAM-D Technologies, Essen, 45117, Germany. ${ }^{3}$ Institute for Bioinformatics and Chemoinformatics, Westphalian University of Applied Sciences, Recklinghausen, 45665, Germany.

\section{Published: 22 March 2013}

\section{References}

1. Schulz SG: The Phase Behavior of Amphiphilic Surfactants and Polymers: A Dissipative Particles Dynamics Study Dissertation, Essen, University of Duisburg-Essen; 2004.

Inorganic Chemistry and Center for Nanointegration, University of DuisburgEssen, Essen, 45141, Germany

Full list of author information is available at the end of the article
2. Steinbeck $C$, Han $Y$, Kuhn $S$, Horlacher $\mathrm{O}$, Luttmann E, Willighagen E: The Chemistry Development Kit (CDK): An open-source Java library for chemo- and bioinformatics. J Chem Inf Comput Sci 2003, 43:493-500.

doi:10.1186/1758-2946-5-S1-P4

Cite this article as: Truszkowski et al: Molecular simulations of peptides and proteins with Molecular Fragment Dynamics (MFD). Journal of Cheminformatics 2013 5(Suppl 1):P4.
Publish with ChemistryCentral and every scientist can read your work free of charge

"Open access provides opportunities to our colleagues in other parts of the globe, by allowing anyone to view the content free of charge."

W. Jeffery Hurst, The Hershey Company.

- available free of charge to the entire scientific community

- peer reviewed and published immediately upon acceptance

- cited in PubMed and archived on PubMed Central

- yours - you keep the copyright

Submit your manuscript here:

http://www.chemistrycentral.com/manuscript/

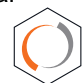

ChemistryCentral 